\title{
Spontaneous evisceration of the appendix through an incisional hernia at rest
}

\author{
Charles West, ${ }^{1}$ James Richards, ${ }^{2,3}$ Vijay Sujendran, ${ }^{4}$ James Wheeler ${ }^{4}$
}

${ }^{1}$ Department of Surgery, Brighton and Sussex University Hospitals NHS Trust, Brighton, Brighton and Hove, UK ${ }^{2}$ Department of Clinical Surgery, The University of Edinburgh, Edinburgh, UK ${ }^{3}$ Department of Surgery, University of Cambridge, Cambridge, UK

${ }^{4}$ Department of Surgery, Addenbrookes Hospital, Cambridge, UK

\section{Correspondence to}

James Richards,

jamesrichards@doctors.net.uk

Accepted 6 September 2016

\section{DESCRIPTION}

A 70-year-old man presented to accident and emergency (A\&E) department with spontaneous rupture of his incisional hernia, which occurred at rest. $\mathrm{He}$ previously had an emergency open abdominal aortic aneurysm repair. Postoperatively he developed a large incisional hernia. On arrival at A\&E department, it was evident that his hernia had eroded through the skin, with his appendix and some greater omentum protruding through the defect (figure 1). There were no clinical features of obstruction or strangulation. He underwent preoperative CT scanning to delineate the anatomy and facilitate operative planning (figure 2); this confirmed a large defect measuring $18 \times 15 \mathrm{~cm}$ containing the bowel and omentum, and evisceration of the appendix.

He underwent an emergency incisional hernia repair with open appendectomy. Given the size of the myofascial defect, a bridging mesh was required to achieve closure. As a result of concern over contamination, a decision was made to use a collagen mesh (Permacoll) rather than a synthetic mesh. An

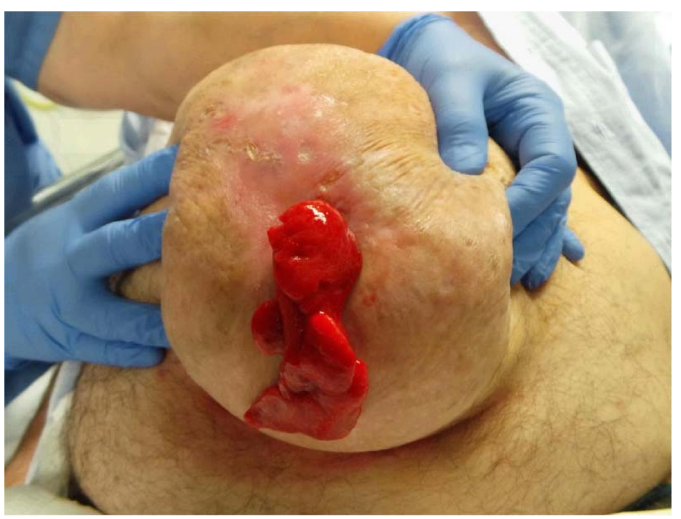

Figure 1 Photograph of eviscerated appendix. abdominal binder was applied postoperatively. $\mathrm{He}$ was discharged on day 6 and reviewed 7 weeks later; there is no evidence of recurrence or infection.

Evisceration of an appendix through an incisional hernia is rare and is usually associated with severe pain. ${ }^{1}$ Spontaneous evisceration through an abdominal wall hernia is more likely on a background of an acute (eg, coughing, exertion) or chronic (eg, ascites) rise in intra-abdominal pressure and is associated with significant morbidity and mortality. ${ }^{2}$ This is the first case we have come across that occurred at rest in the absence of ascites.

\section{Learning points}

- Incarceration, strangulation and obstruction are not the only emergency presentations of abdominal wall hernias.

- It is not unreasonable to treat asymptomatic abdominal wall hernias conservatively in high risk patients; however, evisceration is a recognised (but rare) risk.

- If spontaneous evisceration occurs, urgent surgical intervention is indicated.

Competing interests None declared.

Patient consent Obtained.

Provenance and peer review Not commissioned; externally peer reviewed.

\section{REFERENCES}

1 Das S, Sarkar S, Ghosh M, et al. Eviscerated 'amyand' incisional hernia. J IMA 2011;43:80-2.

2 Chatzizacharias NA, Bradley JA, Harper S, et al. Successful surgical management of ruptured umbilical hernias in cirrhotic patients. World I Gastroenterol 2015;21:3109-13.
To cite: West C, Richards J, Sujendran V, et al. BMJ Case Rep Published online: [please include Day Month Year] doi:10.1136/bcr-2016217585

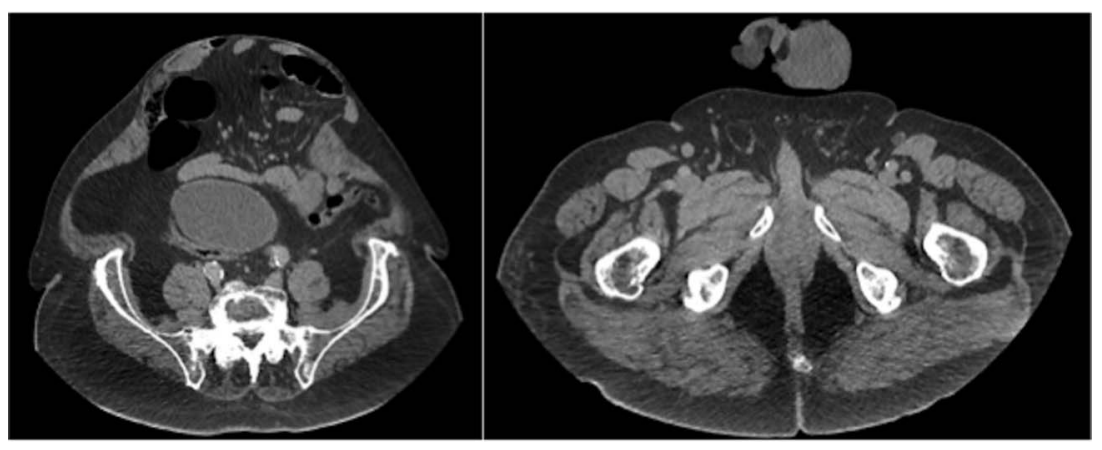

Figure 2 CT scan of the abdomen/pelvis with contrast showing large incisional hernia defect and eviscerated appendix. 
Copyright 2016 BMJ Publishing Group. All rights reserved. For permission to reuse any of this content visit http://group.bmj.com/group/rights-licensing/permissions.

BMJ Case Report Fellows may re-use this article for personal use and teaching without any further permission.

Become a Fellow of BMJ Case Reports today and you can:

- Submit as many cases as you like

- Enjoy fast sympathetic peer review and rapid publication of accepted articles

- Access all the published articles

- Re-use any of the published material for personal use and teaching without further permission

For information on Institutional Fellowships contact consortiasales@bmjgroup.com

Visit casereports.bmj.com for more articles like this and to become a Fellow 